\title{
THE RELATION BETWEEN THE CRUDE FIBRE CONTENT OF FOOD AND THE MILK PRODUCTION ${ }^{1}$ ]
}

\author{
P. SCHOORL
}

Veterinary Faculty Dept. of Nutritional Science, University of Indonesia, Bogor

\section{Summary}

The principal reason why Frisian Holstein cows under the tropical conditions of Indonesia produce much less milk is, according to this author, not due to the climate but to the composition of the food. The grass is always of a reedy quality and also the concentrates with large quantities of rice hulls possess too much crude fibre. Consequently, as a result of the necessarily forced digestion, the heat balance of the cow becomes overloaded and because there is no outlet for this heat, she decreases her digestion intensity, which results in a decrease of the resorption of the necessary foodstuff and the milk production becomes lower than normal.

The author has succeeded in growing a better kind of grass with a lower content of crude fibre and a higher protein content in quantities of 120 tons per ha yearly. When also the concentrates are composed of materials paor in crude fibre, the milk production should increase with a rather high percentage.

It is a well-known fact, that the Frisian-Holstein cow under tropical conditions does not produce as much milk as in a moderate climate.

This is very regrettable as these animals are very expensive to buy and to maintain in Indonesia. This makes that the price of milk is high and that milk only can be used by the man in the street as a medicine.

The average milk production of the Frisian-Holstein cow in Holland is ca 3.800 liter in 300 milking days, whereas the same cow in Indonesia does not produce more than 1.500 liter or probably less. The lactation period generally is also much shorter: about 240 days.

The result of these facts is, that the relative high efficiency of the convertion of food into milk is much lower than normal, which fact is further stressed by the very high rations they get and the abnormal long inter-calving periods.

The general opinion on these phenomena is that it is due to the tropical climate with its high temperature and great humidity.

It is true that there are several newly imported cows which show an increased respiration frequency during their entire life. There even exist purebred Frisian Holstein cows, born in Indonesia, which show the same high breathing-frequency. These cows show a typical sign of non-acclimatisation; they cannot get rid of the heat which is produced and this demonstrates clearly that there is something wrong with the heat balance of these cows.

Studies made by the Institute for Animal Breeding in Bogor on the quantity and composition of the food consumed by the Frisian Holstein cow in Indonesia taught that the cows get much more food than they need according to the feeding standards of MorRIson or those of KeLLNER or FrEDERIKSON, some special cases excepted. The following average data will illustrate this observation. By an average live weight which, in general, does not differ much from

1) Received for publication August 20, 1954. 
$450 \mathrm{~kg}$, the 840 cows from 27 farms studied got the following rations with a daily average milk production of 5.6 liter.

\begin{tabular}{|c|c|}
\hline Grass (or other green roughage) & 40 \\
\hline Ricebran (coarse) $\ldots \ldots \ldots \ldots$ & 4 \\
\hline Wet soybean offall & 4 \\
\hline Brewers grain (wet). & 5 \\
\hline Rice polishings $\ldots \ldots$ & 0.6 \\
\hline Coconut-meal & 1.8 \\
\hline
\end{tabular}

According to the analytical data from the Governmental Chemical Laboratory in Bogor this ration contains $1.2 \mathrm{~kg}$ digestible true protein and $9.2 \mathrm{Starch}$ Aequivalent Units, whereas they need no more than $0.5 \mathrm{~kg}$ digestible true protein and 3.8 Starch Aequivalent Units. This is more than twice the amount needed; consequently, lack of food cannot be the cause of the low average milk production. There is more reason to think of too much of one or another substance. Certainly, there must be something wrong with the digestion or with any other feeding circumstance!

The high food consumption and the low milk production in connection with the registered high breathing frequency of some cows and the tropical climate make it probable that there is something wrong with the heat balance.

If we study the normal heat-balance of a cow with a production of 20 liters of milk as has been done by MöllgaARD, we get the following data.

The daily ration for a milkcow with more than 201 milk analyzed by MöllgaARD, contained a bruto energy of $50.436 \mathrm{Cal}$, together with the $1177 \mathrm{Cal}$ from some body-fat, which was assimilated, the daily energy income of this experimental cow was $51.613 \mathrm{Cal}$. The output was divided into the following categories :

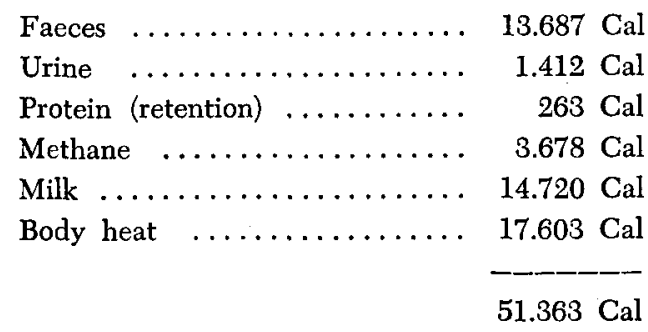

From these data we see that, under normal conditions, a cow with a production of 22 liters of milk loses $25 \%$ of the bruto calory income of the food with the faeces (undigested calories). With the milk $29 \%$ of the energy leaves the body whereas $34 \%$ is converted into body heat. The rest, only $12 \%$, is lost with partly oxidized products such as urea in the urine and the methane from the bowel.

Other data given by MANGOLD teach us, that there is a great difference in the part of the bruto energy of different foodstuffs which are converted into body-heat as a result of the digestion-work done by the chewing, the rumination, the bowelfunction etc., indicated as Thermical Energy in the table below. These differences are closely related to the crude fibre content of the food. 


\begin{tabular}{|c|c|c|c|c|c|c|c|c|c|}
\hline \multirow[b]{2}{*}{ Foodstuff } & \multirow[b]{2}{*}{ 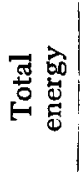 } & \multicolumn{3}{|c|}{ Energy lost by } & \multirow[b]{2}{*}{ 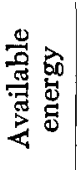 } & \multicolumn{2}{|c|}{ Therm. energy } & \multirow[b]{2}{*}{ 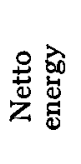 } & \multirow{2}{*}{ 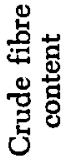 } \\
\hline & & $\begin{array}{c}\text { Faeces } \\
\%\end{array}$ & $\begin{array}{c}\text { Methane } \\
\qquad \%\end{array}$ & $\begin{array}{c}\text { Urine } \\
\qquad\end{array}$ & & $\begin{array}{l}: \text { Total } \\
\text { energy }\end{array}$ & $\begin{array}{c}\% \text { Avail- } \\
\text { able } \\
\text { energy }\end{array}$ & & \\
\hline $\begin{array}{l}\text { Corn } \ldots \ldots \\
\text { Hay } \\
\text { Straw } \\
\ldots \ldots\end{array}$ & $\begin{array}{l}100 \\
100 \\
100\end{array}$ & $\begin{array}{l}12 \\
48 \\
59\end{array}$ & $\begin{array}{l}9 \\
7 \\
8\end{array}$ & $\begin{array}{l}4 \\
4 \\
2\end{array}$ & $\begin{array}{l}75 \\
41 \\
31\end{array}$ & $\begin{array}{l}29 \\
17 \\
26\end{array}$ & $\begin{array}{l}39 \\
42 \\
84\end{array}$ & $\begin{array}{r}46 \\
24 \\
5\end{array}$ & $\begin{array}{r}2.7 \\
21.9 \\
40.8\end{array}$ \\
\hline
\end{tabular}

This table shows that from a product poor in crude fibre, such as corn (wheat and rice belong to the same category in this respect) even $39 \%$ of the available energy is needed for digestion purposes and converted into bodyheat. For a good quality of hay this percentage is not much higher, but for a product with much crude fibre such as straw, more than $80 \%$ is converted into heat and lost for production purposes. That there is no greater difference between corn and first quality of hay can be explained by the fact that the raw fibre of good hay is easily digested and provides also a relatively large portion for production purposes, which is not the case with the raw fibre of straw.

Now it is easily understood that cattle from a temperate climate which receive much food which is rich in crude fibre has to get rid of this heat and, consequently, have much trouble.

When we study the first table showing the average ration given in Indonesia and pay some attention to the crude fibre and bruto energy content, we get the following data:

\begin{tabular}{|c|c|c|c|c|c|}
\hline & & & $\begin{array}{c}\text { Crude } \\
\text { fibre } \\
\%\end{array}$ & $\begin{array}{c}\text { Crude } \\
\text { fibre } \\
\text { in grams }\end{array}$ & $\begin{array}{l}\text { Bruto } \\
\text { energy } \\
\text { in Cal. }\end{array}$ \\
\hline \multirow[t]{2}{*}{$\begin{array}{l}40 \\
4 \\
4 \\
1 \\
0.6 \\
1.8\end{array}$} & \multirow[t]{2}{*}{$\begin{array}{l}\mathrm{kg} \text { grass } \\
\text { " rice offall } \\
\text { " soya offall } \\
\text { " brewersgrain } \\
\text { " rice polishings } \\
\text { " coconutcake }\end{array}$} & \multirow[t]{2}{*}{$\begin{array}{l}\text { with } \\
\text { " } \\
" \\
" \\
"\end{array}$} & \multirow[t]{2}{*}{$\begin{array}{r}7.4 \\
16.4 \\
3.2 \\
17.2 \\
7.4 \\
8.8\end{array}$} & $\begin{array}{r}2960 \\
664 \\
128 \\
172 \\
44 \\
158\end{array}$ & $\begin{array}{r}37400 \\
14400 \\
2000 \\
900 \\
2200 \\
6500\end{array}$ \\
\hline & & & & 4126 & 63400 \\
\hline
\end{tabular}

This ration contains $4.1 \mathrm{~kg}$ crude fibre and $63400 \mathrm{Cal}$ whereas a normal ration with normal grass (thus no Bengalese or Elephant grass as is mostly fed in Indonesia) and with a good quality rice bran (without hulls) contains only $2.4 \mathrm{~kg}$ crude fibre.

According to Zuntz, raw fibre has a specific dynamic action of producing $2 \mathrm{Cal}$ extra for $1 \mathrm{~g}$ of crude fibre, so that the unnecessary dose of raw fibre produces 3448 Calories.

In my opinion, a high crude fibre content is a very unfavourable factor in 
the heat-balance of a cow in the tropics : she produces milk, from which production process extra calories come free from the udder. Obviously, this will have an unfavourable influence upon both the digestion intensity and the milk production.

Because a cow cannot transpire as other animals (horse, man) this overproduction of calories should be avoided and this is only possible by a less intensive digestion, which, in its turn, will be the cause of an insufficient resorption of the foodstuffs most necessary for milk production, such as proteins and minerals.

My experience in Indonesia is that the average raw fibre content in the dry matter of raw materials such as grass and other green food lies between $35-40 \%$ and of the concentrates between 10 and $15 \%$, whereas in Holland productive cows only get $20-25 \%$ raw fibre in the raw material and 5-10\% raw fibre in the concentrates.

It is easily understood that cattle from temperate countries, which receive much food rich in raw fibre may succeed in regulating their heat balance by increasing their breathing frequency, but it is more acceptable that the power of the digestive tract is lowered, so that the "available energy"-percentage is decreased and the ration as a whole is less well digested. The result will be a decreased milk production, which in that way is not a direct result of the climate but of the composition of the food.

The only correct remedy against this phenomenon is to give the lactating cow a ration which is more easily digestable than that which is usually given. This can be done by giving a better kind of grass in the form of well manured young meadow-grass instead of the reedy grasses rich in crude fibre which are commonly used at present.

Growing meadow grass is easy enough in this country as has been proved by several trials in Bogor. For this purpose no imported grasses are needed. Any grass field - along the roads, in gardens and parks and also the grass on fallow-land - can be used with great success, when it is manured well ; when dressings of sulfate of ammonia are combined with potassium chloride in quantities of $1000 \mathrm{~kg}$ for $I$ ha for each cut, it is possible to produce $30-40.000 \mathrm{~kg}$ per cut of a good quality of grass with $15-20 \%$ crude protein in the dry material. (A yearly production of over $120.000 \mathrm{~kg}$ a ha has been reached already).

It must be rather easy to prove this statement by analyzing the faeces of some cows, which receive a ration rich in crude fibre and from some others, which receive a ration poor in crude fibre and so to see if there is a comparatively large difference; another trial should make a comparison between the milk production of two herds of the same quality which are fed in different ways.

The first trial (the analyzing of faeces) will be done here as soon as experimental animals are at hand; neither the necessary utensils for digestion trials nor the experienced analysts and assistants are available to carry out this experiment.

The only possibility I had until now, was to feed a Frisian Holstein cow from the Veterinary Faculty, which in her first lactation period yielded the following monthly milk production (daily recorded). 
1st Lactation period

1951-1952

Date of calving 14-10-1951

Production: October $1951 \ldots \ldots \ldots \ldots \ldots 145$ liters

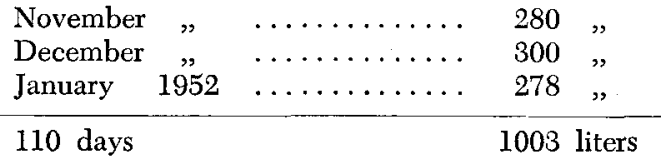

During this period this cow got enough reedy grass (Pennisetum maximum) and a mixture of corn, rice offall with a large quantity of hulls and coconutmeal.

Her next lactation period began 21-5-1953 and now we got the following records :

2nd Lactation period

1953-1954

Date of calving 21-5-1953

Production: May $1953 \ldots \ldots \ldots \ldots \ldots \ldots$ liters

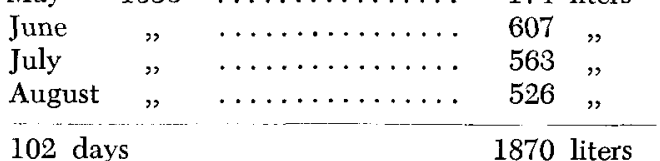

These periods are not quite identical, because from October to January it is the wet season and from May to August it is the dry season, but this difference is in favour of the first lactation.

We perceive, that the milk production is nearly doubled in the second lactation period. For the greater part this must be the result of the change in the composition of the food, for this cannot be explained solely by the normal increase in age.

The cow now received $40 \mathrm{~kg}$ normal young meadow grass with $3.0 \%$ protein in the fresh material and a concentrate mixture of maize, fine rice bran, coconutmeal, peanutmeal and soymeal; consequently, the crude fibre content was much lower than before. 